\title{
Submarine Groundwater Discharge as a Source of Mercury in the Bay of Puck, the Southern Baltic Sea
}

\author{
Beata Szymczycha $\cdot$ Michał Miotk • \\ Janusz Pempkowiak
}

Received: 17 December 2012 / Accepted: 20 March 2013 /Published online: 4 May 2013

(C) The Author(s) 2013. This article is published with open access at Springerlink.com

\begin{abstract}
Both groundwater flow and mercury concentrations in pore water and seawater were quantified in the groundwater seeping site of the Bay of Puck, southern Baltic Sea. Total dissolved mercury $\left(\mathrm{HgT}_{\mathrm{D}}\right)$ in pore water ranged from 0.51 to $4.90 \mathrm{ng} \mathrm{l}^{-1}$. Seawater samples were characterized by elevated $\mathrm{HgT}_{\mathrm{D}}$ concentrations, ranging from 4.41 to $6.37 \mathrm{ng} \mathrm{l}^{-1}$, while $\mathrm{HgT}_{\mathrm{D}}$ concentrations in groundwater samples ranged from 0.51 to $1.15 \mathrm{ng} \mathrm{l}^{-1}$. High $\mathrm{HgT}_{\mathrm{D}}$ concentrations in pore water of the uppermost sediment layers were attributed to seawater intrusion into the sediment. The relationship between $\mathrm{HgT}_{\mathrm{D}}$ concentrations and salinity of pore water was non-conservative, indicating removal of dissolved mercury upon mixing seawater with groundwater. The mechanism of dissolved mercury removal was further elucidated by examining its relationships with both dissolved organic matter, dissolved manganese (Mn II), and redox potential. The flux of $\operatorname{HgT}_{\mathrm{D}}$ to the Bay of Puck was estimated to be $18.9 \pm 6.3 \mathrm{~g} \mathrm{year}^{-1}$. The submarine groundwater discharge-derived mercury load is substantially smaller than atmospheric deposition and riverine discharge
\end{abstract}

\footnotetext{
B. Szymczycha $\cdot$ M. Miotk $\cdot$ J. Pempkowiak Institute of Oceanology, Polish Academy of Sciences, ul. Powstancow Warszawy 55, 81712 Sopot, Poland

J. Pempkowiak $(\bowtie)$

Faculty of Construction and Environmental Engineering, Koszalin University of Technology,

ul.Śniadeckich 2,

75453 Koszalin, Poland

e-mail: pempa@iopan.gda.pl
}

to the Bay of Puck. Thus, groundwater is a factor that dilutes the mercury concentrations in pore water and, as a result, dilutes the mercury concentrations in the water column.

Keywords Gulf of Gdańsk · Loads · Mercury · Submarine groundwater discharge $\cdot$ Seepage water

\section{Introduction}

Submarine groundwater discharge (SGD) is one of the water pathways connecting land and ocean in the global water cycle. It has been recognized as an important factor influencing coastal zones (Burnett et al. 2006; McCoy and Corbett 2009; Szymczycha et al. 2012). Groundwater, similarly to surface water, flows along a hydraulic gradient, thus entering directly into the sea, wherever a coastal aquifer exists. While the contribution of groundwater discharges can be comparatively minor, particularly in the areas dominated by large rivers flows, studies have shown that groundwater is an important fraction of freshwater outflow (Burnett et al. 2006). Moreover, as groundwater is most often enriched with chemical constituents, it can be a source of substantial loads of nutrients, trace metals, and organic compounds (Charette and Sholkovitz 2006; Szymczycha et al. 2012).

The knowledge of SGD nutrient loads as a factor enhancing coastal eutrophication is relatively well established (Valiela et al. 2002). Moreover, there is a growing interest in the concentrations and loads of trace constituents delivered to the coastal zone through 
SGD (Charette and Sholkovitz 2006; Beck et al. 2010). Studies concerning mercury concentrations in seepage water and their impact on the marine ecosystem have recently indicated the ecological and geochemical importance of SGD. In this respect, some of the recent studies devoted to mercury distribution in SGD-impacted areas indicate enriched concentrations of mercury there. Laurier et al. (2007) reported an increase in total dissolved mercury $\left(\mathrm{HgT}_{\mathrm{D}}\right)$ in seawater and enhanced mercury uptake by mussels in the groundwater-impacted area (the Pays de Caux, France). This phenomenon was explained by high $\mathrm{HgT}_{\mathrm{D}}$ concentrations in estuarine water that resulted in mercury partitioning to the dissolved or colloidal phase in response to changes in salinity and/or turbidity. Bone et al. (2007) reported that the main driver of mercury flux was the low organic carbon content of the aquifer sediments and emphasized the complexity of mercury transport within groundwater systems. Tiffreau et al. (1995) suggested that mercury will desorb from metal (hydr)oxides at increasing concentrations of chloride through the formation of soluble $\mathrm{Hg}-\mathrm{Cl}$ complexes. Lamborg et al. (2004) assumed that dissolved organic carbon (DOC) should exert a greater impact on mercury speciation than chloride. Thus, there is a need for data characterizing both mercury concentrations in seepage water and mercury behavior upon the mixing of groundwater and seawater.

Research on mercury concentration levels in the Gulf of Gdańsk has been performed for many years. It has focused on determining mercury concentrations in surface water, sediments, and marine fauna and flora (Pempkowiak et al. 1998; Bełdowski and Pempkowiak 2003, 2007; Kuss and Schneider 2007; Bartnicki et al. 2009; Pohl and Hennings 2008; Bełdowski et al. 2009; Saniewska et al. 2010). The main sources of mercury in the Gulf of Gdańsk and the Bay of Puck were identified to be atmospheric deposition (Bełdowska et al. 2012), river discharge (Pempkowiak et al. 1998), shipyards, harbors, wastewater treatment plants, and the municipal areas of Gdańsk, Gdynia, and Sopot. However, there are no available data concerning mercury fluxes via SGD in the Gdańsk Basin or for the entire Baltic Sea. This paper reports on the results of studies on mercury distribution in seepage water discharged to the Bay of Puck, southern Baltic Sea. In addition, $\mathrm{HgT}_{\mathrm{D}}$ concentrations in the groundwater and seawater were determined. $\mathrm{HgT}_{\mathrm{D}}$ flux via SGD into the Bay of Puck was estimated and compared to other mercury fluxes.

\section{Materials and Methods}

\subsection{Study Area}

The SGD area was identified in the shallow, littoral zone of the Bay of Puck (Fig. 1), (Pempkowiak et al. 2010; Szymczycha et al. 2012). The Bay of Puck is part of the Gulf of Gdańsk in the southern Baltic. It is a shallow, sandy, wave-dominated bay, well known for its high eutrophication rates due to anthropogenic impact (Kotwicki et al. 2011). The area of the study site equals some 9,200 $\mathrm{m}^{2}$ and is located off the Hel Peninsula, which has evolved during the Holocene. The coast of the peninsula is basically recent alluvial and littoral zone of Holocene sediments from 10 to $100 \mathrm{~m}$ in thickness (Korzeniewski 2003). The sediments of the study area are influenced by three major processes: seepage of groundwater, intrusion of seawater into the surface layer of sediments, and sedimentary processes including mineralization of organic matter deposited in the sediments. The last process is limited to the uppermost layer of sediments, while seawater can be forced into the sediments to a depth of some decimeters (Szymczycha et al. 2012). The seawater intrusion into the sediments depends on several factors: seepage intensity, the granulometric properties of sediments, water depth, sea bottom relief, and wave action. These features are specific to both the particular sampling points and hydrodynamic conditions at the time of sampling (Szymczycha et al. 2012).

\subsection{Sampling}

The study area was located near the shoreline of the Hel Peninsula $\left(54^{\circ} 36^{\prime} 25^{\prime \prime} \mathrm{N}, 18^{\circ} 47^{\prime} 57^{\prime \prime} \mathrm{E}\right)$. The sampling campaigns were carried out in the following periods: 2-6 November 2009, 28 February to 1 March 2010, and 5-7 May 2010. The selection of sampling points was based on the results of salinity surveys (Szymczycha et al. 2012). The pore water samples were collected at two separate seepage water discharge points located at close proximity (groundwater lance I (GL I) and groundwater lance II (GL II)), once a day, by means of groundwater lances described by Beck et al. (2007). In the course of each sampling campaign, seawater samples were also collected close to the sea floor. Moreover, in May 2010, pore water samples from sediments without apparent groundwater 
Fig. 1 Map of the Bay of Puck with the study area indicated as a square and sampled groundwater wells: HI (Hel), WI

(Władysławowo), RI (Reda I), RII (Reda II), RIII (Reda III). RI is a Tertiary aquifer at $41 \mathrm{~m}$ depth RII is a Quaternary aquifer at $15.7 \mathrm{~m}$ depth, RIII is a Craterous aquifer at $178 \mathrm{~m}$ depth,

$\mathrm{H} 1$ and $\mathrm{W} 1$ are Pleistocene aquifers at $170 \mathrm{~m}$ and $122.5 \mathrm{~m}$ depth respectively

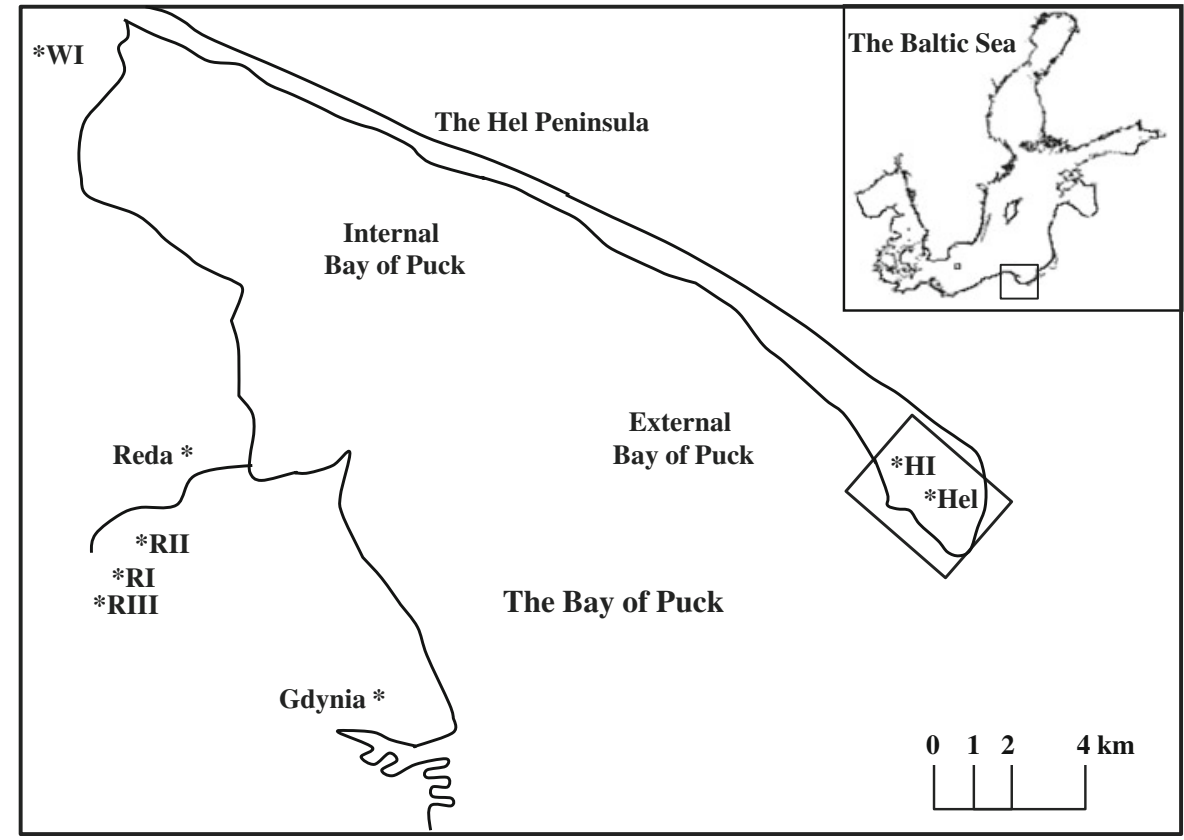

discharge were also collected (groundwater lance (GL)), as well as groundwater samples from wells situated on the shores of the Bay of Puck. Thus, several water types were collected as part of the study: sediment pore water (either groundwater (salinity below 1) or seepage water (salinity from 1 to 6.9)), seawater, and groundwater from land-based wells (salinity less than 0.5 ). Salinity and oxidationreduction potential (ORP) measurements were performed on the samples with a multimeter (WTW Multi 3400i Multi-Parameter Field Meters). During the sampling campaigns, 13 pore water profiles were obtained, each comprising pore water samples collected from five to six depths below sediment-water interface. Pore water profiles at subsequent sampling points were characterized by pore water salinity profiles presented in Fig. 2.

Special care was taken to prevent contamination of collected samples. All components of the groundwater lances used for collecting pore water samples were soaked in a bath, filled with $3 \mathrm{M} \mathrm{HNO}_{3}$, for 1 day. After acid treatment, samplers were rinsed five times with MilliQ water, including ports and tubing. The entire equipment was wrapped in a number of layers of heavy plastic sheeting for transport. The groundwater lances were installed in the sediment and then allowed to equilibrate for $\sim 24 \mathrm{~h}$, with the free sample tube ends. After the equilibration period, the sample tubes were each attached to dedicated, acid-washed, all-PE 50-ml syringes with short sections of acidcleaned Teflon tubing. Each syringe, in turn, was detached and connected to an acid-washed 25-mm diameter, $0.45-\mu \mathrm{m}$ pore size, polypropylene syringe filter. A total of $35 \mathrm{ml}$ of pore water was collected from several depths $(0,4,8,12,16,24$, and $30 \mathrm{~cm})$ below sediment-water interface. The collected water samples were divided into separate vials to be analyzed for the following components: $\mathrm{HgT}_{\mathrm{D}}$, DOC, and dissolved manganese $(\mathrm{Mn})$. The samples meant for $\mathrm{HgT}_{\mathrm{D}}$ analysis were transferred into acid-washed borosilicate test tubes with Teflon-lined caps. Samples meant for $\mathrm{Mn}$ analysis were transferred into acid-washed 20-ml LDPE bottles and acidified to $\mathrm{pH}<2$ with supra pure $0.1 \mathrm{~N} \mathrm{HNO}_{3}$. Samples used for DOC analysis were transferred to parched glass vials and acidified with $40 \mu \mathrm{l}$ of concentrated $\mathrm{HCl}$. Groundwater samples from deep (water) wells and seawater samples were collected into vials, prepared in the same manner as the borosilicate bottles for $\mathrm{HgT}_{\mathrm{D}}$ analysis.

\subsection{Analysis}

The samples for $\mathrm{HgT}_{\mathrm{D}}$ analysis were oxidized by $\mathrm{BrCl}$ and then pre-reduced with hydroxylamine hydrochloride solution $1 \mathrm{~h}$ prior to analysis by CV-AFS 
November, 2009
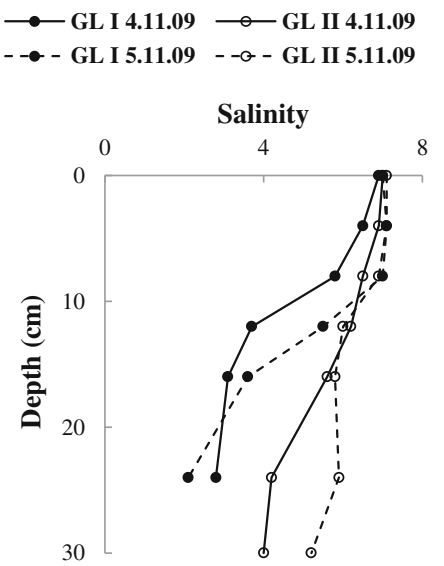

February, 2010

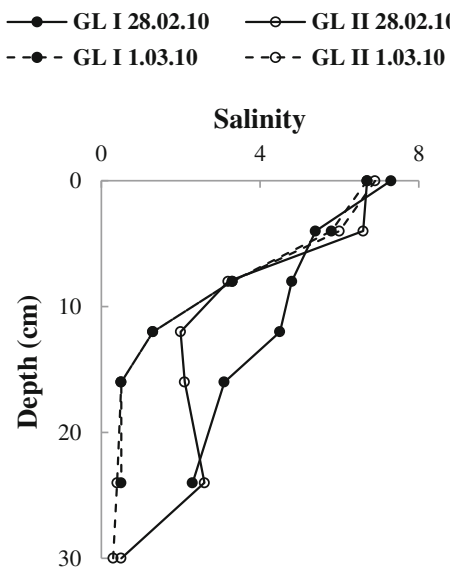

May, 2010

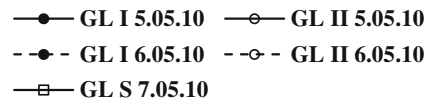

$\longrightarrow$ GL S 7.05.10

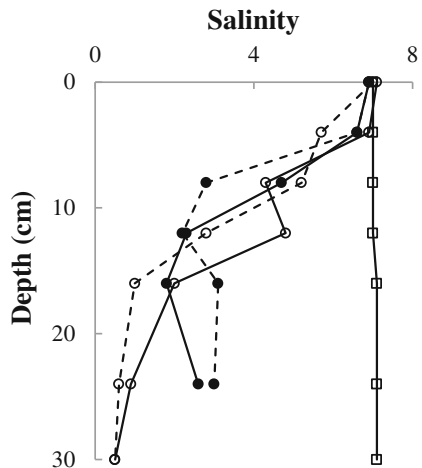

Fig. 2 Salinity distribution in the study area. $G L$ groundwater lance, $I$ and $I I$ separate locations in groundwater-impacted area. $G L S$ groundwater lance located in the area without apparent groundwater impact

(TEKRAN 2600, Canada), according to US EPA method 1631 (US EPA 2002). Quality control included the analysis of blanks $(n=5)$ and estimating accuracy and precision based on the analysis of water samples $(n=5)$ (groundwater, seepage water, and seawater) spiked with mercury nitrate in the range of $0.5-$ $2.5 \mathrm{ng} \mathrm{Hg} \mathrm{l}^{-1}$. Adequate precision (6\%, given as relative standard deviation (RSD)) and recovery (95 $\pm 1 \%$ ) were obtained throughout the study. Moreover, during each sampling campaign, procedural blank samples $(n=3)$ were run. The obtained $\operatorname{HgT}_{\mathrm{D}}$ concentrations of the procedural blank samples were in the range $0.21-0.24 \mathrm{ng} \mathrm{Hg} \mathrm{l}^{-1}$ and never exceeded $10 \%$ of concentrations measured in the actual samples. The detection limit of the method used for $\mathrm{HgT}_{\mathrm{D}}$ analysis was equal to $0.2 \mathrm{ng} \mathrm{Hg}^{-1}$.

Concentrations of Mn were determined by ICPMS (Elan 9000, Perkin Elmer). Analysis of standard reference material (SLEW 3) and groundwater samples spiked with Mn $\left(5 \mu \mathrm{g} \mathrm{l}^{-1}\right)$ served as a quality check. Average recovery of $\mathrm{Mn}$ was $103 \%$, and precision given as RSD was $0.3 \%(n=5)$.

Samples for DOC were analyzed with UV/persulfate oxidation and non-dispersive infrared detection (HyPerTOC, Thermo Electron Corp.). The limit of detection of the method was smaller by an order of magnitude than the measured concentrations. The precision of the results given as RSD was better than $2 \%$ DOC, while recovery tested against the SGW standard was $96 \%$.

\section{Results}

3.1 Salinity Distribution in the SGD-Impacted Area

Samples of 12 pore water profiles were collected in the groundwater-impacted area (GIA) and an additional profile in an area without apparent groundwater impact. The pore water salinity profiles are presented in Fig. 2. Generally, in the GIA profiles, salinity decreased with depth. The GL I 4.11.09 and GL I 5.11.09 profiles present salinity decrease from 7.1 and 6.9 to 2.8 and 2.1, respectively. In profiles GL II 4.11.09 and GL II 5.11.09, salinity decreased from 7 and 7.1 to 4 and 5.2, respectively, while in the GL II 28.02.10 and GL II 1.03.10 profiles, salinity decreased from 7.1 and 6.3 to 0.5 and 0.3 , respectively. At the GL I 28.02.10 profile, salinity decreased from 6.7 to 2.3 , while on the following day, salinity deceased to 0.3 . In May 2010, similarly to November 2009, two groups of salinity profiles can be distinguished. Samples collected at location GL I show a salinity decrease from 7.1 to about 2.6, while samples collected at location GL II show a salinity decrease down to 0.5 . The salinity profile in the location apparently unaffected by seepage discharges, GL S 7.05.10, shows constant salinity values of about 7 (Fig. 2). The changes in salinity distribution in GIA are caused by seawater intrusion into the sediment due to wave action and hydrodynamic conditions at the time of sampling (Szymczycha et al. 2012). Seawater can penetrate seepage sites to depths of tens of centimeters 
due to thermohaline density effects (Bokuniewicz 1992). Previous studies of SGD sites have indicated sediment pore water salinity profiles similar to those described here (Beck et al. 2007a; Beck et al. 2010; Pempkowiak et al. 2010). Therefore, for practical purposes, during this study, pore water samples characterized by salinity $<1$ were attributed to groundwater. Those characterized by salinity in the range $1<\mathrm{S}<6.9$ were attributed to seepage water (mixture of seawater and groundwater), and the ones with salinity $S \geq 7$, to seawater.

\subsection{Mercury Distribution in the SGD-Impacted Area}

Ranges of $\mathrm{HgT}_{\mathrm{D}}$ concentrations in the water samples collected in the study area are presented in Table 1 . The measured $\mathrm{HgT}_{\mathrm{D}}$ concentrations spanned a relatively wide range ( 0.51 to $\left.6.37 \mathrm{ng}^{-1}\right)$. The seawater samples were characterized by $\mathrm{HgT}_{\mathrm{D}}$ concentrations ranging from 4.41 to $6.37 \mathrm{ng} \mathrm{l}^{-1}$. These values were comparable to those measured earlier in the Gulf of Gdańsk and the Bay of Puck seawater (Boszke 2005; Bełdowski et al. 2009; Saniewska et al. 2010). $\mathrm{HgT}_{\mathrm{D}}$ concentrations in the water samples collected from the wells located on the Hel Peninsula were lower than $3.29 \mathrm{ng} \mathrm{l}^{-1}$. Generally, $\mathrm{HgT}_{\mathrm{D}}$ in the groundwater (pore water salinity $<1$ ) and seepage water (salinity in the range 1.0 to 6.9 ) ranged from 0.51 to $4.90 \mathrm{ng} \mathrm{l^{-1 }}$. Fig. 3 presents depth profiles of $\mathrm{HgT}_{\mathrm{D}}$ and salinity in the 12 pore water profiles of GIA. The average dissolved mercury concentrations decreased from $3.76 \pm 0.71 \mathrm{ng}^{-1}$ to $2.03 \pm 0.59 \mathrm{ng}^{-1}$ in November 2009. In February 2010, $\mathrm{HgT}_{\mathrm{D}}$ concentration decreased from $2.96 \pm 0.48 \mathrm{ng} \mathrm{l}^{-1}$ to $0.54 \pm 0.04 \mathrm{ng} \mathrm{l}^{-1}$, while in May 2010, $\mathrm{HgT}_{\mathrm{D}}$ concentrations decreased from $4.33 \pm 0.57 \mathrm{ng} \mathrm{l}^{-1}$ to $0.91 \pm 0.31 \mathrm{ng} \mathrm{l}^{-1}$. The average $\operatorname{HgT}_{\mathrm{D}}$ concentrations and standard deviations were calculated from all measured $\mathrm{HgT}_{\mathrm{D}}$ concentrations. The calculated standard deviations of the average concentrations indicated substantial variations of $\mathrm{HgT}_{\mathrm{D}}$. The average concentrations of $\mathrm{HgT}_{\mathrm{D}}$ in groundwater were much lower than those in seawater. The Bay of Puck is under the influence of nearby industrial and urban areas of Gdynia and Gdańsk. This means the presence of abundant atmospheric (Boszke 2005) and point sources (Saniewska et al. 2010) of mercury discharge into the environment. As a consequence, concentrations of mercury in the waters of the Bay of Puck were measured as ranging from 2.1 to $8.19 \mathrm{ng} \mathrm{l}^{-1}$ (Bełdowski et al. 2009), much greater than concentrations in waters of the open Baltic Sea (Pempkowiak et al. 1998). Thus, the profiles presented in Fig. 3, showing the decrease of $\mathrm{HgT}_{\mathrm{D}}$ downward in sediment pore water, are caused by the mixing of highmercury seawater and low-mercury groundwater. The seawater end-member is characterized by higher $\mathrm{HgT}_{\mathrm{D}}$ concentration than groundwater end-member. Thus, $\mathrm{HgT}_{\mathrm{D}}$ concentrations were set by seawater intrusion into the sediment. The pore water profiles GL II 28.02.10, GL I 1.03.10, GL II 1.03.10, GL 5.05.10, GL II 5.05.10, GL 6.06.10, and GL II .6.06.10 were all characterized by elevated $\mathrm{HgT}_{\mathrm{D}}$ concentrations in the uppermost $15 \mathrm{~cm}$ and then a downward decrease of the concentrations. Meanwhile, the profiles GL I 4.11.09, GL II 4.11.09, GL I 5.11.09, GL II 5.11.09, and GL I 28.02.10 illustrated higher seawater intrusion resulting in much smaller $\mathrm{HgT}_{\mathrm{D}}$ concentration decrease. Such a pattern is typical of a highly dynamic mixing zone of a subterranean estuary (Beck et al. 2007a).

DOC distribution (Fig. 3) in the pore water also indicated the mixing of the two end-members (seawater and groundwater). Both end-members of the
Table 1 Concentrations of $\mathrm{HgT}_{\mathrm{D}}$ in the collected water samples

Pore water samples characterized by salinity $<1$ were attributed to groundwater. Those characterized by salinity in the range $1<\mathrm{S}<6.9$ were attributed to seepage water, and $S \geq 7$ to seawater

\begin{tabular}{|c|c|c|c|c|}
\hline \multirow[t]{2}{*}{ Sample type } & \multirow[t]{2}{*}{ Salinity } & \multicolumn{3}{|c|}{$\operatorname{HgT}_{\mathrm{D}}$ concentrations $\left(\mathrm{ng} \mathrm{l}^{-1}\right)$} \\
\hline & & Number of samples & $\begin{array}{l}\text { Range } \\
\text { (low-high) }\end{array}$ & Average \\
\hline Seawater & $\mathrm{S}>7$ & 10 & $4.41-6.37$ & 5.44 \\
\hline \multicolumn{5}{|l|}{ Pore water } \\
\hline Seawater & $\mathrm{S}>6.9$ & 9 & $3.21-5.31$ & 4.12 \\
\hline Seepage water & $1<\mathrm{S}<6.9$ & 57 & $0.51-5.04$ & 2.18 \\
\hline Groundwater & $\mathrm{S} \leq 1$ & 11 & $0.51-1.15$ & 0.63 \\
\hline Groundwater from wells & $0.5<\mathrm{S}$ & 5 & $0.50-3.29$ & 1.15 \\
\hline
\end{tabular}




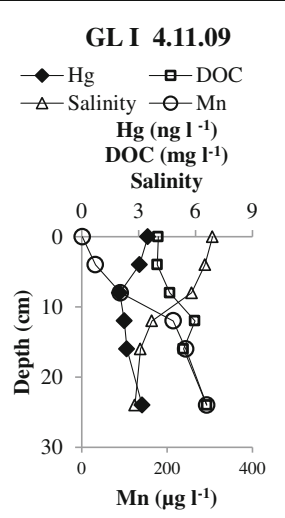

GL I 28.02.10

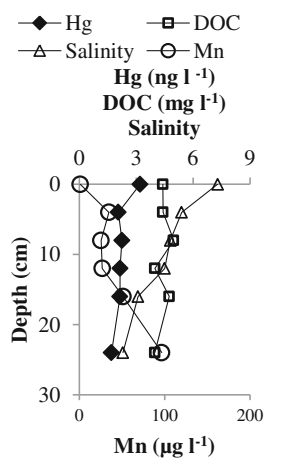

GL I 5.05.10

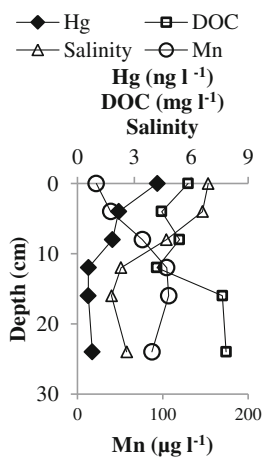

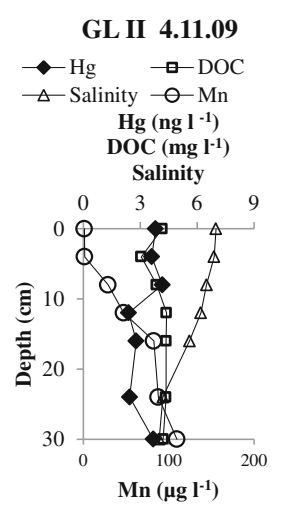

GL II 28.02.10

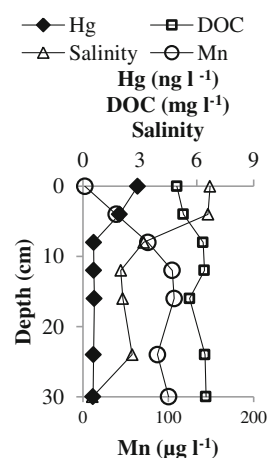

GL II 5.05.10
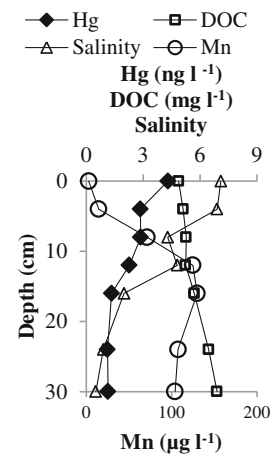

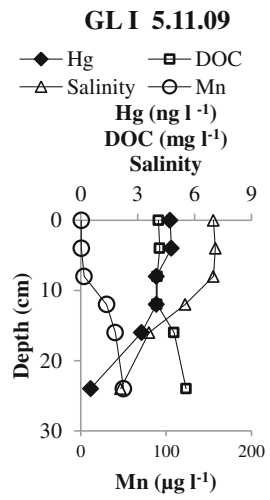

GL I 1.03.10

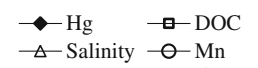

$\mathrm{Hg}\left(\mathrm{ng} \mathrm{l}^{-1}\right)$

$\operatorname{DOC}\left(\mathrm{mg} \mathrm{l}^{-1}\right)$

Salinity

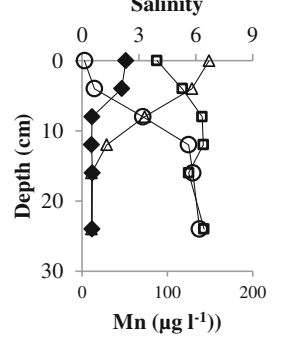

GL I 6.05.10
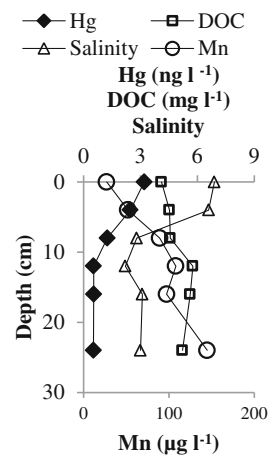

GL II 5.11.09

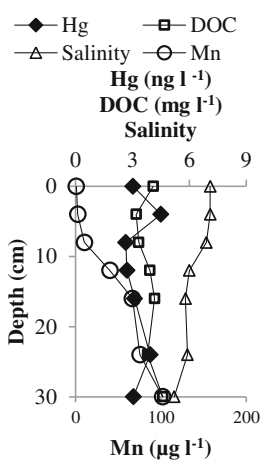

GL II 1.03.10

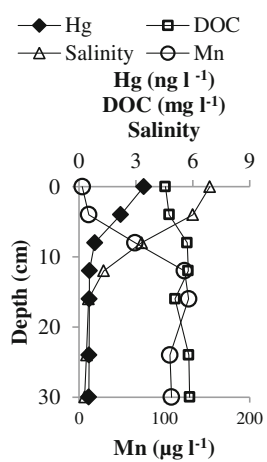

GL II 6.05.10

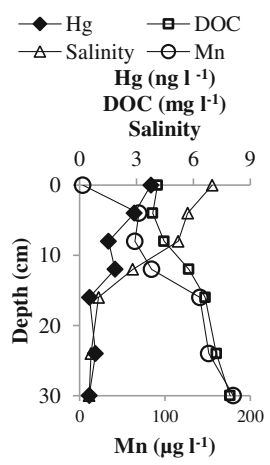

Fig. 3 Pore water depth profiles for total dissolved mercury, dissolved manganese, dissolved organic carbon, and salinity in the groundwater-impacted area. GLI groundwater lance I, GLII groundwater lance II

system represented considerably differing concentrations of organic substances. DOC distribution in pore water profiles was characterized by lower DOC concentrations in the uppermost $15-\mathrm{cm}$ depth in the sediment and higher DOC concentrations in subsurface, lower pore water samples. Average DOC concentrations increased from $4.10 \pm 0.05 \mathrm{mg}^{-1}$ to $5.24 \pm$ $1.06 \mathrm{mg} \mathrm{l}^{-1}$ in November 2009, from $4.47 \pm$ $0.41 \mathrm{mg} \mathrm{l}^{-1}$ to $5.69 \pm 1.17 \mathrm{mg} \mathrm{l}^{-1}$ in February 2010 , and from $4.38 \pm 0.36 \mathrm{mg} \mathrm{l}^{-1}$ to $6.99 \pm 1.28 \mathrm{mg} \mathrm{l}^{-1}$ in May 2010. Dissolved Mn concentrations in pore water profiles (Fig. 3), similarly to DOC, increased with increasing depths. Average Mn concentrations in November 2009 increased from $1.10 \pm 0.33 \mu \mathrm{g} \mathrm{l}^{-1}$ to $87.31 \pm 59.22 \mu \mathrm{g} \mathrm{l}^{-1}$; in February 2010, Mn concentrations increased from $2.53 \pm 1.13 \mu \mathrm{g} \mathrm{l}^{-1}$ to $103.27 \pm$ $5.75 \mu \mathrm{g} \mathrm{l}^{-1}$; and in May 2010, Mn concentrations increased from $13.94 \pm 12.50 \mu \mathrm{g} \mathrm{l}^{-1}$ to $129.10 \pm$ 
$39.71 \mu \mathrm{g} \mathrm{l}^{-1}$. Thus, the selected profiles (GL II 28.02.10, GL I 1.03.10, GL II 1.03.10, GL 5.05.10, GL II 5.05.10, GL 6.06.10, and GL II .6.06.10) all illustrate significant changes in $\mathrm{HgT}_{\mathrm{D}}, \mathrm{DOC}$, and $\mathrm{Mn}$ concentrations starting from a depth of $15 \mathrm{~cm}$ in the sediment upward, suggesting a significant influence of the mixing process between seawater and groundwater on the distribution of the measured constituents in pore water of the GIA.

In Fig. 4, the dependences between $\mathrm{HgT}_{\mathrm{D}}$ concentrations in pore water and salinity are presented. As expected, there is a $\operatorname{HgT}_{\mathrm{D}}$ concentration increase with increasing salinity. The distribution of $\mathrm{HgT}_{\mathrm{D}}$ in the GIA showed greater $\operatorname{HgT}_{\mathrm{D}}$ concentrations in seawater and lower in groundwater. The end-members of the system, namely seawater and groundwater, can be easily identified. The dependences presented in Fig. 4 indicate a non-conservative behavior of mercury upon the mixing of high-mercury seawater and lowmercury groundwater. This is manifested by the departure from a straight line connecting concentrations of the two end-members of the system. This indicates that there are constituents of pore water that can impact $\operatorname{HgT}_{\mathrm{D}}$ distribution in natural waters (Lamborg et al. 2004; Ravichandran 2004). The dependences presented in Fig. 4 suggest that $\mathrm{HgT}_{\mathrm{D}}$ is removed from pore water; however, it is not clear what mechanism is responsible for the removal. The sorption of $\mathrm{HgT}_{\mathrm{D}}$ on solid phase, complexation by organic substances, uptake by biota, and precipitation/co-precipitation all may be responsible for the phenomenon. Coprecipitation is likely to occur since the uppermost layer of sediments in the study area is characterized by a steep redox gradient (Bełdowski and Pempkowiak 2007). Groundwater is characterized by the lack of oxygen, contrary to seawater, which is saturated with oxygen. Thus, a redoxcline forms where mixing of the two water types occurs. Under such conditions, dissolved manganese abundant in groundwater as $\mathrm{Mn}$ (II) is oxidized to $\mathrm{Mn}$ (IV) (Schulz and Zabel 2006). The latter forms highly insoluble manganese hydroxides, which precipitate. Also, complexes of mercury with groundwater dissolved organic substances may flocculate when salinity increases due to seawater intrusion into sediments and its mixing with groundwater (Laurier et al. 2007). The mechanisms of $\operatorname{HgT}_{\mathrm{D}}$ removal may be further elucidated by examining its relationships with dissolved organic matter and dissolved manganese.
The relationship of $\operatorname{HgT}_{D}$ concentrations versus DOC concentrations are presented in Fig. $5 . \mathrm{HgT}_{\mathrm{D}}$ concentrations decreased with the increase of DOC concentrations. The dependences between $\mathrm{HgT}_{\mathrm{D}}$ concentrations and DOC concentrations are nonconservative, although in one case the dependences approach a linear one (GL I, November 2009). Ravichandran (2004) stated that $\mathrm{HgT}_{\mathrm{D}}$ can be associated with a specific fraction of DOC, and as a result, a correlation between total DOC and $\operatorname{HgT}_{D}$ is difficult to establish. Our results may indicate that organic matter differs seasonally with regard to affinity to inorganic mercury. This is in line with earlier data by Pempkowiak (1983) regarding the composition of organic substances and Pempkowiak et al. (2010) and Szymczycha et al. (2012), who suggested seasonally varying provenance of groundwater in the study area.

$\mathrm{HgT}_{\mathrm{D}}$ concentrations versus $\mathrm{Mn}$ concentrations are presented in Fig. 6. $\mathrm{HgT}_{\mathrm{D}}$ concentrations decrease as Mn concentrations increase. This is in line with small $\mathrm{HgT}_{\mathrm{D}}$ concentrations in groundwater which, in turn, is characterized by high dissolved manganese concentrations. The dependences between $\operatorname{HgT}_{\mathrm{D}}$ concentrations and $\mathrm{Mn}$ concentrations are non-conservative suggesting, possibly, pathways for $\mathrm{HgT}_{\mathrm{D}}$ removal caused by co-precipitation with manganese oxides in the mixing of groundwater and seawater.

Thus, the groundwater impact on $\mathrm{HgT}_{\mathrm{D}}$ distribution cannot be fully explained through the observation of geochemical components measured in this study (salinity, DOC, and Mn), suggesting that other processes still drive the distribution of mercury in sediment pore water in the study site. The groundwater-seawater mixing interface should be further investigated to understand the driving processes of mercury distribution.

3.3 The Dissolved Mercury Fluxes to the Study Area Via SGD

$\mathrm{HgT}_{\mathrm{D}}$ concentrations (Table 1) and the groundwater discharges established earlier (Szymczycha et al. 2012) were used to calculate mercury fluxes via SGD. The SGD rates were equal to $18.41 \mathrm{day}^{-1} \mathrm{~m}^{-2}$ in November 2009, 3.01 day $^{-1} \mathrm{~m}^{-2}$ in February 2010, and 3.61 day $^{-1} \mathrm{~m}^{-2}$ in May 2010. The $\mathrm{HgT}_{\mathrm{D}}$ fluxes calculated as a product of the groundwater discharge rate and the measured concentrations of the dissolved mercury were equal to $9.70 \pm$ $0.70 \mathrm{ng} \mathrm{day}{ }^{-1} \mathrm{~m}^{-2}$ in November $2009,1.60 \pm$ 
Fig. 4 The dependences between total dissolved mercury and salinity in the pore water profiles (November 2009, February 2010, and May 2010). GL I groundwater lance I, GL II groundwater lance II. Solid line represents conservative mixing of groundwater with seawater
GL I, November, 2009

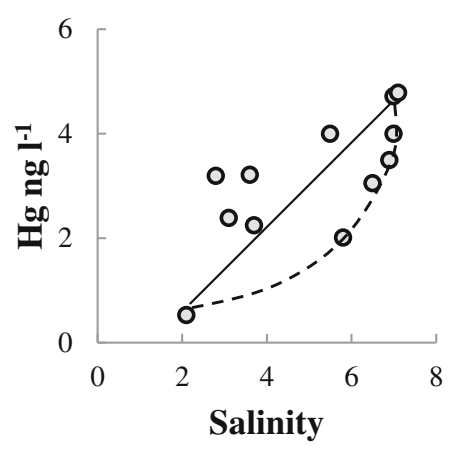

GL I, February, 2010

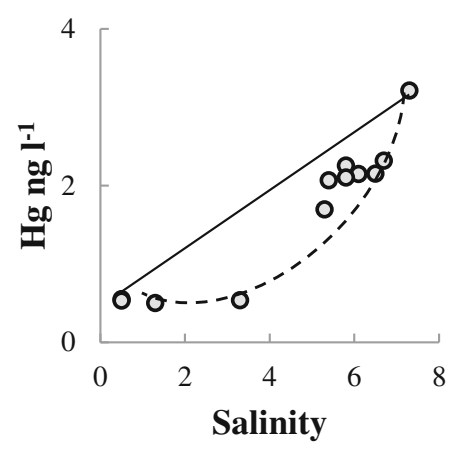

GL I, May, 2010

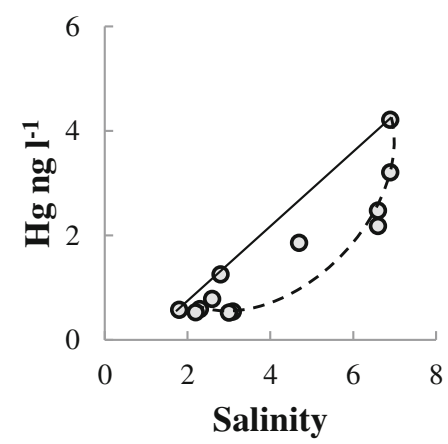

GL II, November, 2009

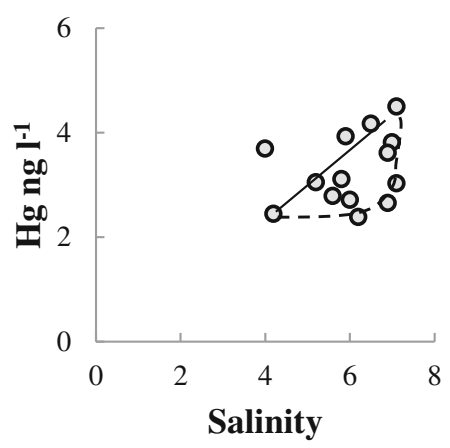

GL II, February, 2010

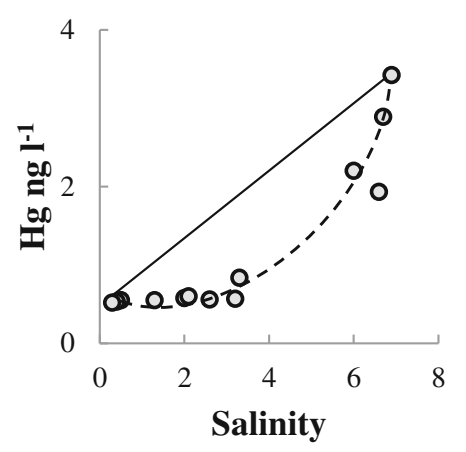

GL II, May,2010

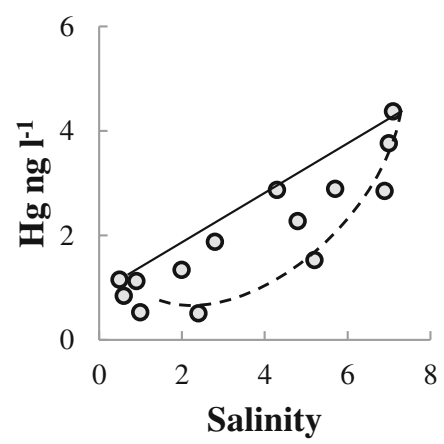

$0.04 \mathrm{ng} \mathrm{day}^{-1} \mathrm{~m}^{-2}$ in February 2010, and 3.00土 $1.12 \mathrm{ng}$ day $^{-1} \mathrm{~m}^{-2}$ in May 2010. Mercury fluxes were highest in November 2009, corresponding to the high SGD rates.

\section{Discussion}

4.1 Mercury Distribution in the GroundwaterImpacted Area of the Bay of Puck

$\mathrm{HgT}_{\mathrm{D}}$ distribution in pore water can be further evaluated by examining Mn and DOC behavior in the study area.
Fig. 7 presents DOC concentrations versus salinity, Mn concentrations versus salinity, and DOC concentrations versus Mn concentrations. All the presented dependences are linear or approaching linear, indicating conservative relationships between the components. The Mn and DOC distribution in the study area can be reasonably explained by both mixing groundwater and seawater and the dissolution of organic matter with Mn release. It can be safely assumed that mercury behave as a non-conservative component of groundwater, while DOC and Mn behave as conservative components of groundwater.

Other processes influencing the distribution of $\operatorname{HgT}_{D}$ concentrations versus ORP, DOC concentrations versus 
Fig. 5 Dependences between total dissolved mercury and dissolved organic carbon in the pore water profiles (November 2009 , February 2010, and May 2010). GL I groundwater lance I, GL II groundwater lance II
GL I, November, 2009

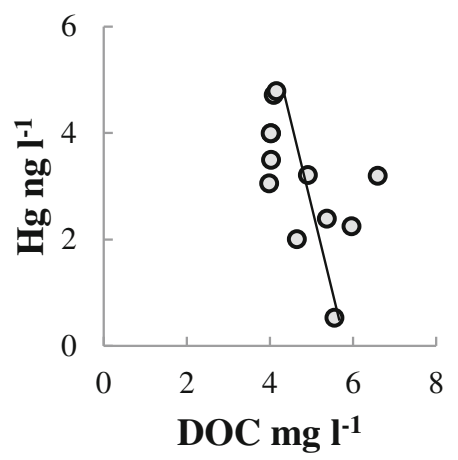

GL I, February, 2010

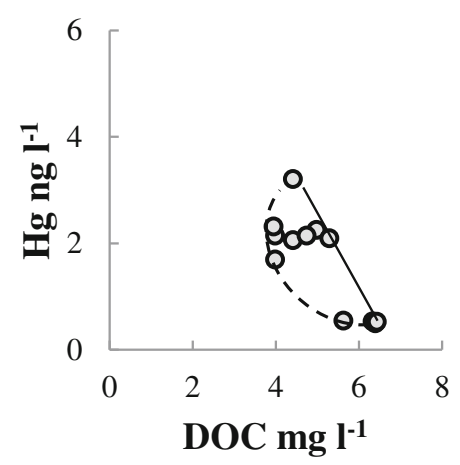

GL I, May,2010

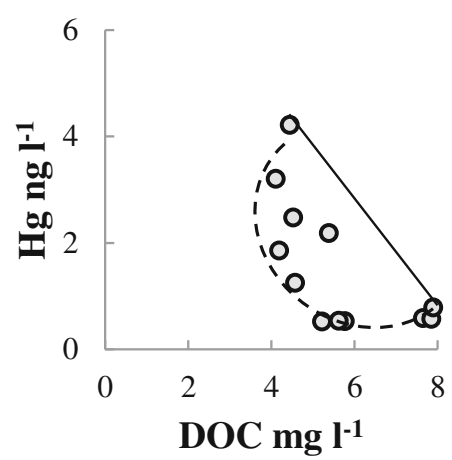

GL II, November, 2009

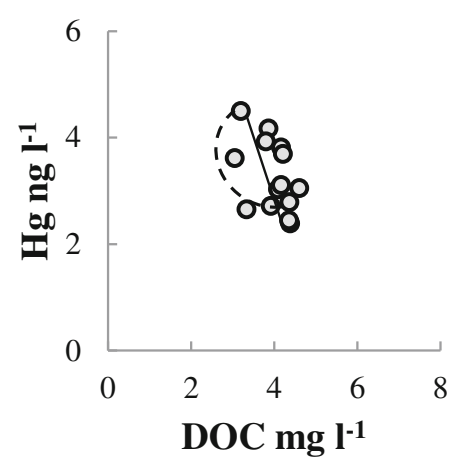

GL II, February, 2010

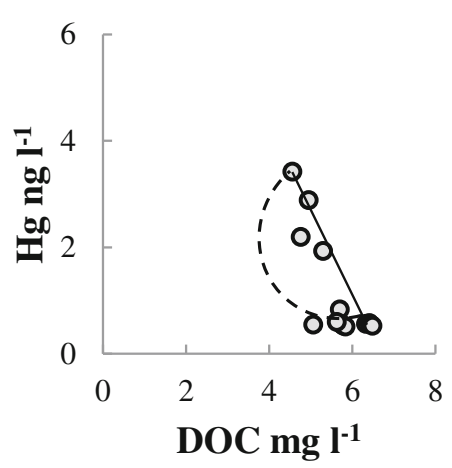

GL II, May,2010

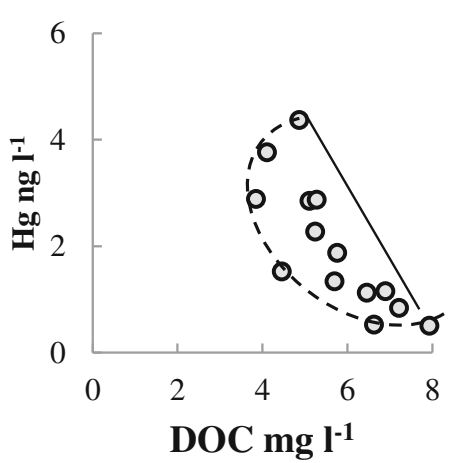

ORP, and Mn concentrations versus ORP are presented in Fig. 8. $\mathrm{HgT}_{\mathrm{D}}$ concentrations decrease with ORP decrease, DOC concentrations increase with ORP decrease, while $\mathrm{Mn}$ concentrations increase with ORP decrease. The presented dependences suggest a nonconservative behavior of mercury versus ORP. This is most likely due to the presence of hydrogen sulphide in groundwater. The sulfate-sulfide cycling is often a major control on transition metals cycling in sediments (Schulz and Zabel 2006) and can be important at this site
(Cai et al. 2003). The pore water samples collected in the groundwater-impacted areas smelled of hydrogen sulphide. Consequently, we could expect sulfate reduction to occur in the mixing of groundwater and seawater. The high concentrations of hydrogen sulphide could be responsible for sulfide mercury precipitation resulting in the dissolved mercury decrease (Schulz and Zabel 2006). The solubility product of mercury sulfite $\left(10^{-41}\right)$ facilitates low concentrations of mercury in groundwater. Dependences between DOC concentrations versus ORP are 
Fig. 6 Dependences between total dissolved mercury and dissolved manganese in pore water profiles (November 2009 , February 2010, and May 2010). GL I groundwater lance I, GL II groundwater lance II. Solid line represents conservative mixing of groundwater with seawater
GL I, November, 2009

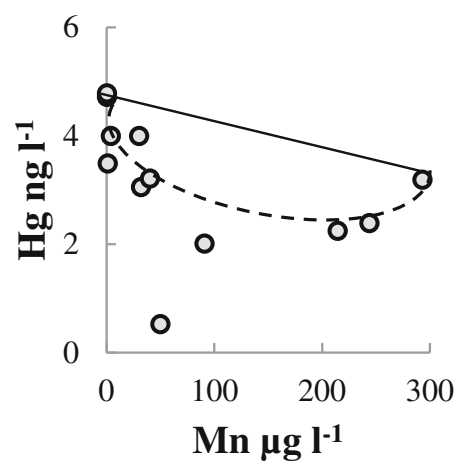

GL I, February, 2010

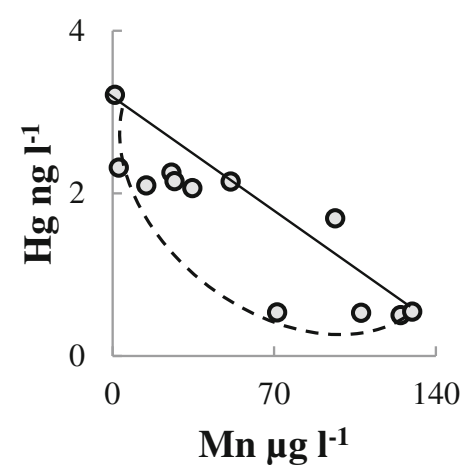

GL I, May,2010

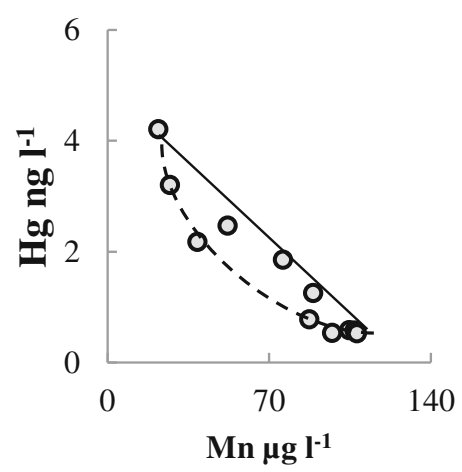

GL II, November, 2009

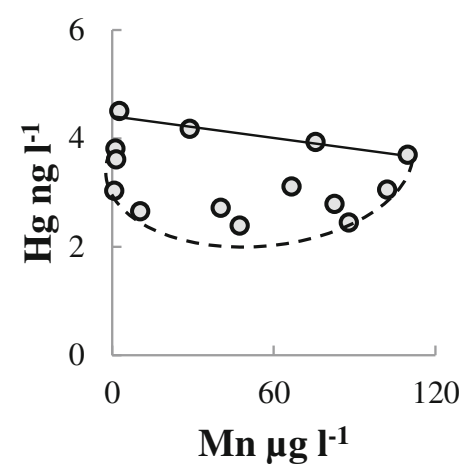

GL II, February, 2010

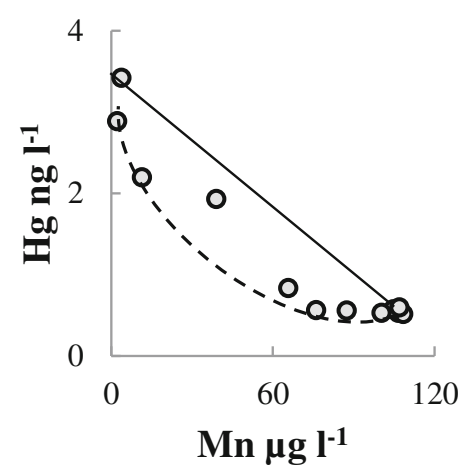

GL II,May,2010

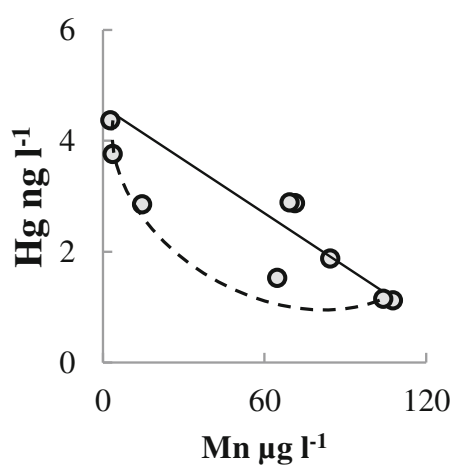

non-conservative, similarly to $\mathrm{Mn}$ concentrations versus ORP.

4.2 The Mercury Fluxes to the Bay of Puck Via SGD

Benthic trace metal release by diffusion from permeable sediments is well documented (Beck et al. 2010). However, during the last decade, it was proven that pore water advection through permeable sediments also represents a significant source of trace metals to coastal waters (Bone et al. 2007; Beck et al. 2007a, 2010). In the Bay of Puck case, the groundwater is characterized by lower $\mathrm{HgT}_{\mathrm{D}}$ concentrations in comparison with seawater. As a result, the groundwater was a factor that dilutes the mercury concentrations in pore water originating from seawater intrusion. Consequently, after stormy events resulting in seawater intrusion into sediments and enriching pore water with mercury, SGD might be 
Fig. 7 Dependences between dissolved organic carbon and salinity, dissolved manganese and salinity, and Mn and DOC concentrations in pore water profiles (November 2009, February 2010, May 2010). Solid line represents conservative mixing of groundwater with seawater

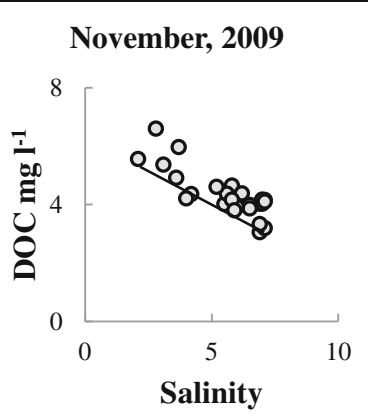

February, 2010

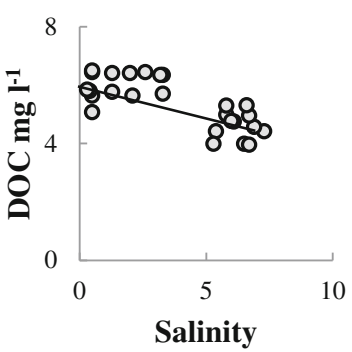

May, 2010

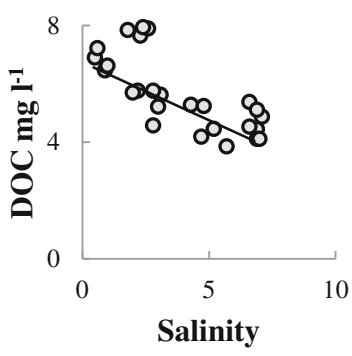

recognized as a significant source of mercury to coastal waters. During this study, we calculated mercury loads via SGD using the characteristic $\mathrm{HgT}_{\mathrm{D}}$ concentrations in the groundwater (Table $1 ; 0.63 \pm 0.21 \mathrm{ng} \mathrm{l}^{-1}$ ) and the known groundwater flux to the Bay of Puck. We believe that only the groundwater is a source of mercury to the ecosystem. A groundwater flux $\left(0.03 \mathrm{~km}^{3}\right.$ year $\left.{ }^{-1}\right)$ was adopted from Korzeniewski (2003). As a result, $\mathrm{HgT}_{\mathrm{D}}$ fluxes via SGD to the Bay of Puck were equal to $18.9 \pm$ 6.3 g year $^{-1}$.

According to Boszke (2005), the Bay of Puck is fairly contaminated with mercury. Mercury mass balance (in- and outflows of mercury to the Bay of Puck ecosystem) calculated by Boszke (2005) showed that between 1.1 and $3.8 \mathrm{~kg}$ year $^{-1}$ of $\mathrm{Hg}$ enters annually from the atmosphere, whereas the load of $\mathrm{Hg}$ carried to the bay with the river water was about seven times lower $\left(0.13-0.44 \mathrm{~kg}\right.$ year $\left.^{-1}\right)$. The budget has proven
November, 2009

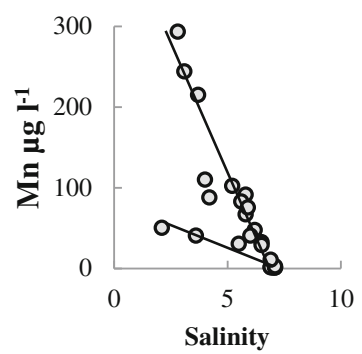

February, 2010

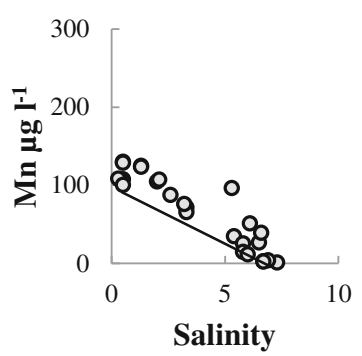

May, 2010

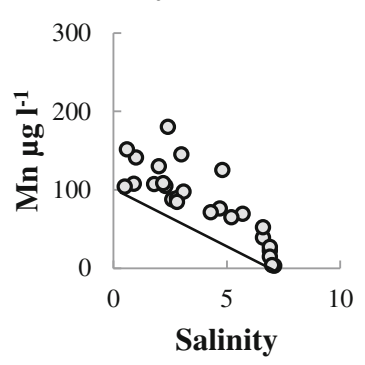

February, 2010

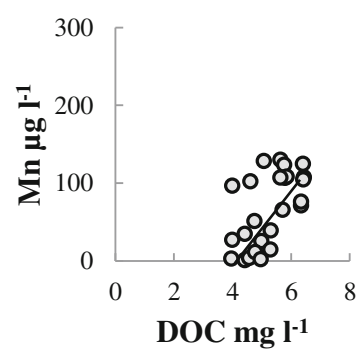

November, 2009

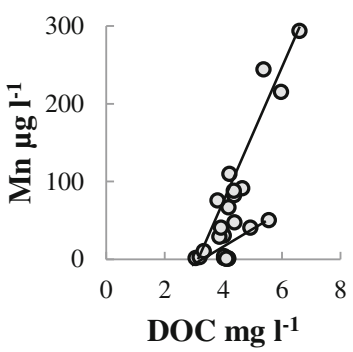

DOC $\mathrm{mg}^{-1}$

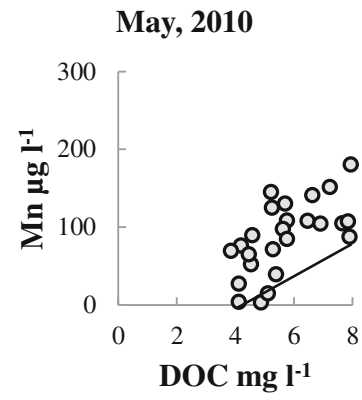

that the main source of mercury in the system is the atmosphere. The mercury fluxes via groundwater discharge appear to be insignificant compared to both the abovementioned sources. The mercury flux obtained in this study is much lower in comparison with other groundwater-impacted areas, e.g., Etretat and Yport along the Pays de Caux Estuary, France (Laurier et al. 2007); Waquoit Bay in Massachusetts, USA (Bone et al. 2007); Elkhorn Slough in Central California, USA (Black et al. 2009); Stinson Beach in Northern California, USA (Black et al. 2009); Hwasun and Bangdu Bays on Jeju Islands, Korea (Lee et al. 2011); and Malibu Lagoon, CA, USA (Ganguli et al. 2012). In Malibu Lagoon, the average mercury flux via SGD was equal to $82.24 \mathrm{ng}$ day ${ }^{-1} \mathrm{~m}^{-2}$, which was higher than that in Hwasun Bay (74.22 $\mathrm{ng}$ day $^{-1} \mathrm{~m}^{-2}$ ) and lower than in Bangdu Bay (158.47 $\mathrm{ng}$ day $^{-1} \mathrm{~m}^{-2}$ ), Stinson Beach $\left(501.48 \pm 320.95 \mathrm{ng}\right.$ day $\left.^{-1} \mathrm{~m}^{-2}\right)$, 
Fig. 8 Dependences between total dissolved mercury and oxidationreduction potential, dissolved organic carbon and ORP, dissolved manganese and ORP in pore water (November 2009, February 2010, and May 2010)
November, 2009

ORP mV

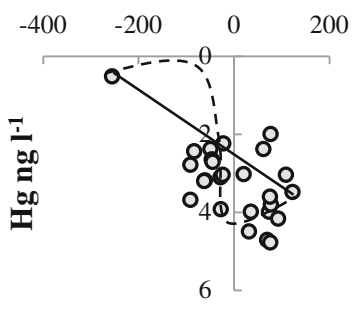

February, 2010
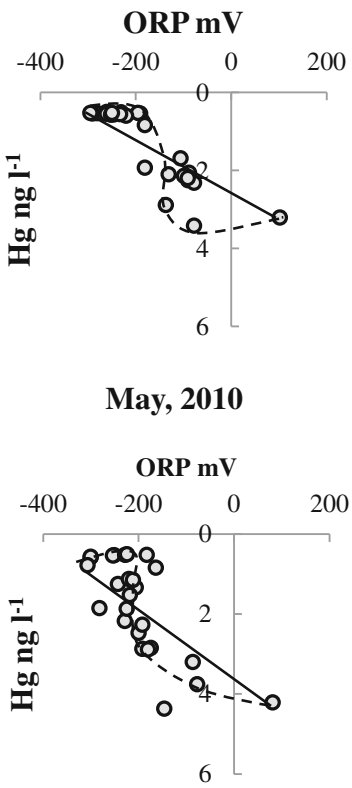

Elkhorn Slough $\left(601.77 \pm 401.18 \mathrm{ng} \mathrm{day}^{-1} \mathrm{~m}^{-2}\right)$, Waquit Beach $\left(94.28 \pm 381.12 \mathrm{ng}\right.$ day $\left.{ }^{-1} \mathrm{~m}^{-2}\right)$, Etretat

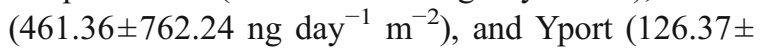
$421.24 \mathrm{ng} \mathrm{day}^{-1} \mathrm{~m}^{-2}$ ). This may be caused by both a lower concentration of mercury and lower SGD correlated with lower discharges of suspended rates in the study area in comparison with the other studies or a combination of these factors.

Thus, there is a need to note and discuss reasons for low concentrations of dissolved mercury in groundwater, much lower than concentrations of dissolved mercury in the wet atmospheric deposition. The water that is recharging the aquifer should have been delivering large mercury loads to the groundwater that are not manifested as increased concentrations of dissolved mercury in groundwater. Most of the load must be retained in the unsaturated and saturated zone
November, 2009

November, 2009
ORP mV

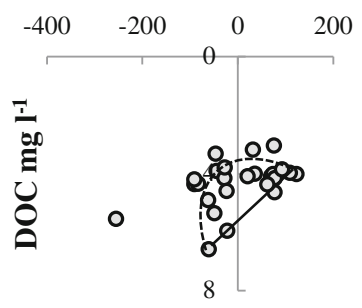

February, 2010

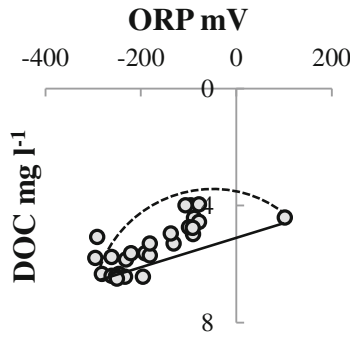

May, 2010

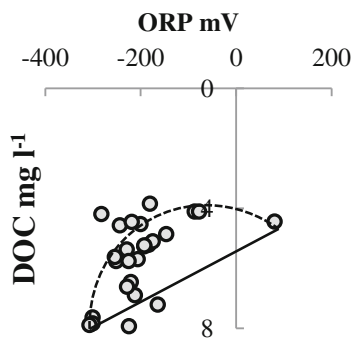

ORP mV

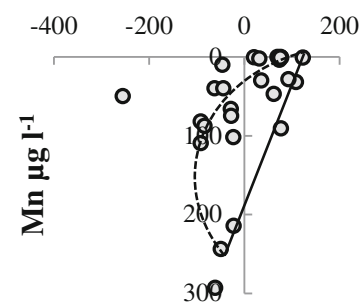

February, 2010

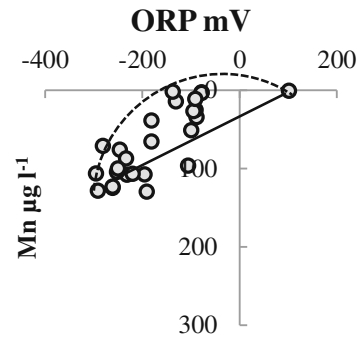

May, 2010

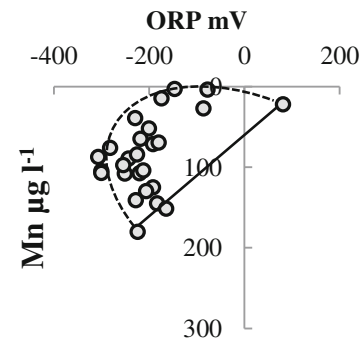

of the surface soil since the groundwater mercury concentrations are low.

Assuming SGD rate to the Bay of Puck at $0.03 \mathrm{~km}^{3}$ (Korzeniewski 2003), the dissolved mercury concentration in rainwater at $8.6 \mathrm{ng} \mathrm{dm}^{-3}$ (Boszke 2005), and the average dissolved mercury concentration in the seeping groundwater at $0.6 \mathrm{ng} \mathrm{dm}^{-3}$ (this study, Table 1), the load of mercury that is retained in the surface soil in rainwater percolating to the saturated zone is equal to $0.03 \mathrm{~km}^{3} \times 10^{9} \mathrm{~m}^{3} / \mathrm{km}^{3} \times(8.6$

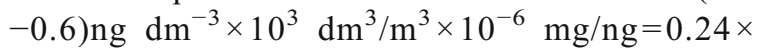
$10^{3} \mathrm{~g}$. The catchment area of the Bay of Puck is close to $100 \mathrm{~km}^{2}$ (Korzeniewski 2003; Kozerski 2007); surface soil is composed of peat and other organicrich deposits and clays (Lidzbarski 2000; Kozerski 2007) that are characterized by high affinity and complexing capacity towards mercury (Boszke et al. 
2008). Thus, it can be safely assumed that yearly

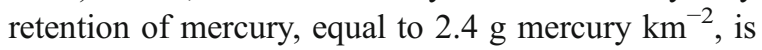
well within a reasonably assumed retention capacity of the catchment. This conclusion agrees well with a very low concentration of mercury in the land-based wells used for extraction of drinking water (this study, Table 1) (Kozerski 2007).

\section{Summary and Conclusions}

Total dissolved mercury concentrations were measured in groundwater, pore water, and seawater in the Bay of Puck. Moreover, concentrations of mercury were measured in groundwater collected from wells located along the coast of the bay and in river water discharged to the bay.

The most important characteristic of the mercury concentrations profile in the groundwater seepage area is high concentrations of dissolved mercury in pore water of the uppermost sediment layer and the decrease of the concentration with depth below the sediment-water interface. This is attributed to seawater intrusion into the sediment.

Mercury behaves non-conservatively in the mixing of low-mercury groundwater and high-mercury seawater. This is caused by mercury removal in mixing seawater and groundwater due to redox reactions. Scaling up the results obtained for the study area indicated that the groundwater seeping to the bay seems not to be a significant source of mercury to the bay ecosystem.

Acknowledgments The study reports the results obtained within the framework of the following projects: statutory activities of the Institute of Oceanology Polish Academy of Sciences theme 2.2 and research projects 3837/B/P01/201039 and 2012/ 05/N/ST10/02761 sponsored by the Polish Ministry of Science and Higher Education.

Open Access This article is distributed under the terms of the Creative Commons Attribution License which permits any use, distribution, and reproduction in any medium, provided the original author(s) and the source are credited.

\section{References}

Bartnicki, J., Gusev, A., Aas, W., Fagerli, H., \& Valiyaveetil, S. (2009). Atmospheric supply of nitrogen, lead, cadmium, mercury and dioxins/furanes to the Baltic Sea in 2007. Centers Joint Report for Helcom, 2.
Beck, A. J., Tsukamoto, Y., Tovar-Sanchez, A., Huerta-Diaz, M., Bokuniewicz, H. J., \& Sañudo-Wilhelmy, S. A. (2007). Importance of geochemical transformations in determining submarine groundwater discharge-derived trace metal and nutrient fluxes. Applied Geochemistry, 22, 477-490.

Beck, A. J., Cochran, J. K., \& Sañudo-Wilhelmy, S. A. (2010). The distribution and speciation of dissolved trace metals in a shallow subterranean estuary. Marine Chemistry, 121, 145-156.

Beck, M., Dellwig, O., Kolditz, K., Freund, H., Liebezeit, G., Schnetger, B., et al. (2007). In situ pore water sampling in deep intertidal flat sediments. Limnology and Oceanography, 5, 136-144.

Bełdowska, M., Saniewska, D., Falkowska, L., \& Lewandowska, A. (2012). Mercury in particulate matter over Polish zone of the southern Baltic Sea. Atmospheric Environment, 46, 397-404.

Bełdowski, J., Miotk, M., \& Pempkowiak, J. (2009). Mercury fluxes through the sediment water interface and bioavibility of mercury in southern Baltic Sea sediments. Oceanologia, 52, 263-285.

Bełdowski, J., \& Pempkowiak, J. (2003). Horizontal and vertical variabilities of mercury concentration and speciation in sediments of the Gdansk Basin, Southern Baltic. Chemosphere, 52, 645-654.

Bełdowski, J., \& Pempkowiak, J. (2007). Mercury concentration and speciation changes along source/sink transport pathway (Southern Baltic). Estuarine, Coastal and Shelf Science, 72, 370-378.

Black, F. J., Paytan, A., Knee, K. L., De Sieyes, N. R., Ganguli, P. M., Gray, E., et al. (2009). Submarine groundwater discharge of total mercury and monomethylmercury to Central California coastal waters. Environmental Science and Technology, 43, 5652-5659.

Bokuniewicz, H. J. (1992). Analytical descriptions of subaqueous groundwater seepage. Estuaries, 15, 458-464.

Bone, S. E., Charette, M. A., Lamborg, C. H., \& Gonneea, M. E. (2007). Has submarine groundwater discharge been overlooked as a source of mercury to coastal waters? Environmental Science and Technology, 41, 3090-3095.

Boszke, L. (2005). Fluxes and balance of mercury in the inner Bay of Puck, southern Baltic, Poland: an overview. Oceanologia, 47, 325-350.

Boszke, L., Kowalski, A., Astel, A., Baranski, A., Gworek, B., \& Siepak, J. (2008). Mercury mobility and bioavailability in soil from contaminated area. Environmental Geology, 55(5), 1075-1087. doi:10.1007/s00254-007-1056-4.

Burnett, W. C., Aggarwal, P. K., Aureli, A., Bokuniewicz, H., Cable, J. E., Charettte, M. C., et al. (2006). Quantifying submarine groundwater discharge in the coastal zone via multiple methods. Science of the Total Environment, 367, 498-543.

Cai, W.-J., Wang, Y.-C., Krest, J., \& Moore, W. S. (2003). The geochemistry of dissolved inorganic carbon in a surficial groundwater aquifer in North Inlet, South Carolina, and the carbon fluxes to the coastal ocean. Geochimica et Cosmochimica Acta, 67, 631-639.

Charette, M. A., \& Sholkovitz, E. R. (2006). Trace element cycling in a subterranean estuary: part 2. Geochemistry of the pore water. Geochimica et Cosmochimica Acta, 70, 811-826.

Ganguli, P. M., Conaway, C. H., Swarzenski, P. W., Izbicki, J. A., \& Flegal, A. R. (2012). Mercury speciation and transport via submarine groundwater discharge at a Southern 
California Coastal Lagoon System. Environmental Science and Technology, 46, 1480-1488.

Korzeniewski, K. (2003). Zatoka Pucka. Gdynia: Instytut Oceanografii Uniwersytetu Gdanskiego.

Kotwicki, L., Grzelak, K., Czub, M., Dellwig, O., Gentz, T., Szymczycha, B., Böttcher, M. (2011) Submarine groundwater discharge to the Baltic coastal zone - impact on meiofaunal community. Journal of Marine Systems, in press.

Kozerski, B. (2007). The Gdańsk hydrogeological system. Gdańsk: Wydawnictwo Politechniki Gdańskiej. 136 pp.

Kuss, J., \& Schneider, B. (2007). Variability of the gaseous elemental mercury sea-air flux of the Baltic Sea. Environmental Science and Technology, 41, 8018-8023.

Lamborg, C. H., Fitzgerald, W. F., Skoog, A., \& Visscher, P. T. (2004). The abundance and source of mercury-binding organic ligands in Long Island Sound. Marine Chemistry, 90, 151-163.

Laurier, F. J. G., Cossa, D., Beucher, C., \& Breviere, E. (2007). The impact of groundwater discharge on mercury partitioning, speciation and bioavailability to mussels in the coastal zone. Marine Chemistry, 106, 352-364.

Lee, Y., Rahman, M. D. M., Kim, G., \& Han, S. (2011). Mass balance of total mercury and monomethylmercury in coastal embayments of a volcanic island: significance of submarine groundwater discharge. Environmental Science and Technology, 45, 9891-9900.

Lidzbarski, M. (2000). Mapa hydrogeologiczna Polski w skali 1:50000. Warszawa: Państwowy Instytut Geologiczny.

McCoy, C. A., \& Corbett, D. R. (2009). Review of submarine groundwater discharge (SGD) in coastal zones of the Southern and Gulf Coast regions of United States with managements implications. Journal of Environmental Management, 90, 644-651.

Valiela, I., Bowen, J. L., \& Kroeger, K. D. (2002). Assessment of models for estimation of land-derived nitrogen loads to shallow estuaries. Applied Geochemistry, 17, 935-953.
Pempkowiak, J. (1983). $\mathrm{C}_{18}$ reversed-phase trace enrichment of short- and long-chain $\left(\mathrm{C}_{2}-\mathrm{C}_{8}-\mathrm{C}_{20}\right)$ fatty acids from dilute aqueous solutions and sea water. Journal of Chromatography, 258, 93-102.

Pempkowiak, J., Cossa, D., Sikora, A., \& Sanjuan, J. (1998). Mercury in water and sediments of the southern Baltic Sea. Science of the Total Environment, 213, 185-192.

Pempkowiak, J., Szymczycha, B., \& Kotwicki, L. (2010). Submarine groundwater discharge (SGD) to the Baltic Sea. Rocznik Ochrony Środowiska, 12, 17-32.

Pohl, C., \& Hennings, U. (2008). Trace metals in Baltic seawater. In: State and Evolution of the Baltic Sea 1952-2005 (pp. 367-393). New York: Wiley.

Ravichandran, M. (2004). Interactions between mercury and dissolved organic matters-a review. Chemosphere, 55, 319-331.

Saniewska, D., Beldowska, M., Beldowski, J., Saniewski, M., Kwaniak, J., \& Falkowska, L. (2010). Distribution of mercury in different environmental compartments in the aquatic ecosystem of the coastal zone of the Southern Baltic Sea. Journal of Environmental Sciences, 22, 1144-1150.

Schulz, H. D., \& Zabel, M. (2006). Marine geochemistry. Berlin: Springer.

Szymczycha, B., Vogler, S., \& Pempkowiak, J. (2012). Nutrients fluxes via submarine groundwater discharge to the Bay of Puck, Southern Baltic. Science of the Total Environment, 438, 86-93.

Tiffreau, C., Kutzenkirchen, J., \& Behra, P. (1995). Modeling the adsorption of mercury(II) on (hydr)oxides. Journal of Colloid and Interface Science, 172, 82-93.

United States Environmental Protection Agency (US EPA) (2002). Method 1631: measurement of mercury in water by oxidation, purge and trap, and cold vapor atomic fluorescence spectrometry. http://water.epa.gov/scitech/ $\mathrm{methods} / \mathrm{cwa} / \mathrm{metals} / \mathrm{mercury} / \mathrm{upload} / 2007$ 07_10_ methods_method_mercury_1631.pdf. 